\title{
INISIASI ETIKA EKSPLORASI PERTAMBANGAN PERSPEKTIF AL-QUR'AN
}

\author{
Nur Arfiyah Febriani ${ }^{1}$, Iin Yuniarni ${ }^{2}$ \\ Institut PTIQ Jakarta, \\ Mahasiswa Pascasarjana Institut PTIQ Jakarta \\ Email:febriani@uinjkt.ac.id,yuniarni@yahoo.com
}

\begin{abstract}
ABSTRAK
Penelitian ini menggagas etika eksplorasi pertambangan perspektif Al-Qur'an yang merupakan bentuk kesadaran metaetika Ilahiyyah yang memiliki sifat kecerdasan reflektif, sebagai reaksi atas adanya "hubungan intensionalitas metaetika teofanik" yaitu hubungan/peran manusia di ranah pertambangan. Sebagai alur pemikiran di dalam penelitian ini, berbasis pada akhlaq profetis Rasulullah Shâllâlahu 'Alaihi wasallam (Hadits Riwayat Abu Dawud) dan etika-ekofenomenologi yang digagas oleh Saras Dewi.

Temuan formulasi etika eksplorasi pertambangan perspektif Al-Qur'an tersebut merupakan pengejewantahan peran manusia yang holistik dan integralistik di dalam mengeksplorasi, memanfaatkan dan melindungi keberadaan sumber daya tambang, dengan pemahaman akan norma-norma moral atas makna kata: Isti'mar, Independensi, Inter-dependensi, Ihsan dan Itqan serta Harmonis adil bersinergis.

Penelitian ini merupakan deskripsi dari tafsîr bayânî dengan corak informatif-transformatif, yang juga merupakan sebuah dukungan terhadap al-tafsîr al-ilmî, beserta seluruh pengembangannya. Penulis menawarkan konformitas baru dalam memahami Al-Qur'an dengan menangkap gagasan utamanya (maghzâ) di balik makna literalnya, dilengkapi dengan pembuktian ilmiah yang teruji secara akademis, argumentatif, proporsional sesuai dengan konteks pengetahuan yang berlaku, melalui tahapan ishtishab (juristic preference). Dengan menggunakan metode tafsîr mâ̂dhu'i, dengan jenis penelitian deskriptif analitik kualitatif, melalui pendekatan ekofenomenologi dipadu dengan analisa dialektika kritis/jadal, dimana prinsip dualitas yang memiliki bentuk dualitas oposisional, antara dua hal yang bersifat material dan atau non material sebagai objeknya, keduanya dipertemukan oleh relasi intensionalitas.
\end{abstract}

Kata Kunci : Pertambangan, Al-Qur'an, Hubungan Manusia 


\section{PENDAHULUAN}

Perilaku masyarakat yang belum sepenuhnya menampakkan kesadaran atas perbuatan manusia yang mengeksplorasi lahan tambang dengan sewenang-wenang, mengeksploitasi hasil tambangnya yang kelewat batas.Belum lagi perbuatan manusia membuang residu pada aktivitas akhir pertambangan yang sembarang, serta manusia yang lalai atas dampak pemanfaatan energi fosil yang over-eksploitatif, Faktor yang ditenggarai menjadi penyebabnya adalah tingginya permintaan akan energi berbahan fosil ini, karena manusia modern sangat memerlukan sumber tambang tersebut sebagai bahan utama energi yang digunakan di kawasan industrial, pabrik-pabrik, pusat perbelanjaan dan juga pada moda tarnsportasi, sebagai penunjuk 'gaya hidup' manusia milenial.

Di dalam istilah ekonomi, ada relasi yang kuat akan permintaan pasar yang tinggi (high demand)- pada komoditas primadona yaitu 'minyak bumi', membuat manusia sangat antusias dan berambisi bertarung di ranah pertambangan untuk memeperole Kejayaan. Faktor kelemahan lainnya pada ranah pertambangan adalah penegakkan hukum yang tidak setimpang, dikarenakan masih adanya 'oknum' yang ingin meraup keuntungan dari kondisi yang ada (rent seeking behaviour).ampak global pertambangan, climate change, sebagai contoh lainnya, hanya satu dari dampak ikutan (coat-tail) eksplorasi pertambangan yang merugikan manusia akibat adanya eksplorasi lahan tambang liar dan juga pengaruh 'life-style' manusia di dalam penggunaan energi berbahan fosil di dalam kehidupan modernnya.

Kompleksnya permasalahan pertambangan sehingga langkah penanggulangannya merupakan suatu dilematis. Pada satu sisi ingin melakukan penegakan hukum dan menghindari dampak yang ditimbulkan pada lingkup area pertambangan. Namun memfokuskan hanya pada satu titik permasalahan tidak akan mampu melepas bingkai keterikatan yang sudah mendarah daging sebagai suatu hal yang biasa. Bahwa secara empiris dapat dikatakan manusia memiliki naluri keserakahan yang sulit dikendalikan, dan bahwa sejarah membuktikan betapa manusia jatuh karena keserakahannya, yaitu kecintaannya pada harta dan kesombongan diri.Hal-hal tersebut di atas terangkum di dalam disertasi ini dengan judul; Etika eksplorasi pertambangan 
perspektif Al-Qur'an sebagai sebuah jawaban yang dibutuhkan sekarang ini dari aktivitas eksplorasi pertambangan.

\section{PEMBAHASAN}

\section{Etika Eksplorasi Pertambangan}

Secara etimologi etika berasal dari bahasa Yunani ethos yang mempunyai banyak arti yaitu: kebiasaan, adat, akhlak, watak, perasaan, sikap, cara pikir. Dalam bentuk jamak (ta etha) artinya adalah adat kebiasaan, arti terakhir inilah terbentuk istilah 'etika' yang digagas oleh filsuf Yunani Aristoteles (384322 SM). Terminologi etika menurut Musa Asy'arie, adalah cabang filsafat yang mencari hakikat nilai-nilai baik dan buruk yang berkaitan dengan perbuatan dan tindakan seseorang, yang dilakukan dengan penuh kesadaran berdasarkan pertimbangan pemikirannya. Persoalan etika adalah persoalan yang berhubungan dengan eksistensi manusia, dalam segala aspeknya. ${ }^{1}$

Etika dalam Beberapa Aliran.:Etika dalam Aliran Naturalisme Perbuatan yang baik menurut aliran ini adalah yang sesuai dengan fitrah manusia, dimana manusia menuju tujuannya itu dengan akalnya. ${ }^{2}$.Etika dalam Aliran Hedonisme Doktrin ini memandang kesenangan sebagai kebaikan yang paling utama dan kewajiban seseorang ialah mencari kesenangan sebagai tujuan hidupnya. Aliran hedonis didukung oleh: Aristippus (356435M) dan Epikuros (270-341 M), Demokritus (460-457 M). ${ }^{3}$. Etika dalam Paham IdealismeKesimpulan akan aliran ini menurut Kant adalah adanya faktor terpenting yaitu 'Kemauan yang baik/good will' sebagai kekuatan manusia di dalam melakukan tindakan-tindakan nyata atas dasar adanya suatu rasa 'kewajiban yang formal yang imperatif', tidak tergantung pada syarat dan kompensasinya. ${ }^{4}$ Etika dalam Paham Utilitarisme Paham ini membahas etika dengan menilai perbuatan baik dan buruk berdasarkan dari besar kecilnya manfa'at bagi manusia. Tokoh paham ini John Stuart Mill (1806-1873 M) menamakan

1 Musa Asy'arie. Filsafat Islam: Sunnah Nabi dalam Berpikir. YogYakarta: LESFI, 2010,cet ke-5. hal. 93.

${ }^{2}$ Hasbullah Bakri. Sistematik Filsafat. Jakarta: Wijaya, 1980, hal. 90.

${ }^{3}$ Graham Gordon. Eight Theories of Ethics. London and New York, Routledge, 2011, hal. 62.

${ }^{4}$ Hasbullah Bakri. Sistematik Filsafat. ..., hal. 97-98. 
perbuatan baik/kebaikan tertinggi (summum bonum) itu adalah utility/manfa'at. ${ }^{5}$

\section{SUMBER DAYA TAMBANG}

Jenis barang tambang adalah termasuk dalam kelompok sumber daya alam yaitu sumbangan bumi berupa benda hidup (living endowments) dan benda mati (non-living endowments). seperti logam, bahan mineral, tanah, air, udara dan lainnya, yang bisa dieksplorasi oleh manusia sebagai sumber makanan, bahan mentah dan energi. Sumber daya alam berada di lingkungan atau bumi yang berfungsi sebagai stok yang diperoleh dari kegiatan ekonomi yang berupa input atau bahan baku (raw materials). ${ }^{6}$

Berdasarkan pemanfaatannya, sumber daya alam dibedakan dalam dua katagori utama, yaitu: Pertama, sumber daya alam yang bisa dimanfaatkan secara langsung (memiliki sifat nonexcludebility dan indivisibility), seperti udara yang segar, air yang bening dari sungai dan danau, bahan makanan dari tanaman dan ternak. Kedua, sumber daya alam yang tidak bisa dinikmati secara langsung atau perlu diolah lebih lanjut (termasuk yang bersifat excludebility dan divisibility), memerlukan persyaratan atas pemakaian tehnologi yang cukup tinggi seperti: minyak, besi, dan memurnikan logam mulia. ${ }^{7}$ Konsep Resources Scarcity

Darwin C. Hall dan Jane V. Hall, Adel Daoud, Gabriel Claudia Mursa, dan Addinul Yakin, menjelaskan dua teori besar tentang resources depletion yaitu:a. Kelangkaan sumber daya absolut (absolute resources scarcity or Malthusian Scarcity). Sistem ekonomi sering bergantung pada satu sumber daya esensial yang memiliki batas tertentu ketersediaannya secara fisik. Sumber daya jenis ini tentu saja bisa habis. Periode kelangkaan absolut ini mulai terjadi ketika permintaan akan sumber daya melebihi penawaran sumber daya tersebut. b.

Ricardian's scarcity (kelangkaan sumber daya relatif), berangkat dari asumsi ekonomi bahwa kebutuhan manusia tidak terbatas sehingga sumber daya menjadi terbatas dan langka. Kelangkaan sumber daya alam relatif bisa terjadi ketika suatu

\footnotetext{
${ }^{5}$ Sudarsono. Ilmu Filsafat. Jakarta: Rieneka Cipta, 2008, hal. 202.

${ }^{6}$ Akhmad Fauzi. Ekonomi Sumber Daya Alam. Jakarta: Gramedia Pustaka Utama, 2006, hal. 6.

${ }^{7}$ Thomas H. Tietenberg dan Lynne Lewis. Enviromental and Natural Resources Economics. New Jersey (USA): Addison: Wesley, 2012, edisi ke-9, hal. 31 .
} 
sumber daya masih cukup tersedia untuk memenuhi kebutuhan, tetapi distribusinya tidak merata dan seimbang.

\section{PERTAMBANGAN}

Terminologi eksplorasi pertambangan, berdasarkan Undang-Undang Republik Indonesia no 4 Tahun 2009 dan Peraturan Pemerintah RI Tahun 2014, disebutkan bahwa pertambangan adalah sebagian atau seluruh tahapan kegiatan dalam rangka penelitian, pengelolaan, dan pengusahaan mineral atau batubara yang meliputi penyelidikan umum, eksplorasi, studi kelayakan, konstruksi, penambangan, pengolahan dan pemurnian, pengangkutan dan pejualan, serta kegiatan pascatambang.

Secara teknis tahapan krusial adalah saat membuka bentang alam, maka kepekaan tersebut dimulai dari masalah yang sederhana sampai pada masalah yang besar dan kompleks. Eksplorasi (exploration) atau juga disebut sebagai ekstrasi, yaitu suatu kegiatan penambangan yang meliputi pekerjaan-pekerjaan pengambilan dan pengangkutan endapan bahan galian atau mineral berharga sampai ke tempat penimbunan dan pengolahan (processing), pemurnian (purification), pengilangan (refinering), kadang-kadang sampai ke tempat pemasaran dan pengangkutan (distribution).

Urgensi peradaban manusia millennia sepenuhnya disokong oleh pertambangan, sedemikian pentingnya kebutuhan manusia terhadap pertambangan sehingga seorang manusia akan terus menggunakan beragam komoditas tambang sepanjang hidupnya. Sejarah pertambangan awal bermulanya sejak 8.000 tahun lalu di Timur tengah dengan ditemukannya penggunaan tembaga di Turki.

Hubungan barang tambang bagi manusia bisa dianalisa melalui tinjauan kebutuhan hidup yang diperbincangkan oleh para ahli antara lain: Al-Syatîbi $(720 \mathrm{H}-790 \mathrm{H}),{ }^{8}$ di dalam teori Maqâshid al-Syarî'ah, dan Ahmad Al-Raisuni yang menjelaskan bahwa tujuan (maqâshid) memiliki sifat dharûriyat, hâjiyat dan tahsîniyyat. ${ }^{9}$ Berdasarkan penelitian ahli bahwa urgenitas sumber tambang berbahan fosil di masa kini digolongkan dalam

${ }^{8}$ Al-Syatibi. Al-Muwafaqad fî Ushul al-Sharî’ah. Beirut: Dâr al-Ma'rifah, 1978, juz. I.

9 Ahmad al-Raisuni. Nadariyât al-Maqâshid 'Inda al-Imâm al-shâtibî. Beirut: Muassah al-Jami’ah, 1992, hal. 116-117. 
kebutuhan yang bersifat Dharûriyat Teori popular Maslow's Hierarchy of Needs Theory, ${ }^{10}$ dengan jelas memerinci kebutuhan dasar manusia saat ini dalam bentuk kebutuhan berjenjang sebagai adanya: 1). Physicological Needs, 2). Safety Needs, 3). Social Needs, 4). Egoistic or Esteem Needs dan 5). Need for SelfActualization.

Kebutuhan dasar ini tidak statis, tetapi bersifat dinamis dan berkembang sesuai dengan tingkat peradaban dan kesejahteraan manusia. Makin sedikit kebutuhan dasar yang tidak dapat dipenuhi maka makin buruk pula kualitas hidupnya. Hal ini mengandung makna bahwa makin tinggi derajad kualitas hidup manusia makin baik kualitas pemenuhan kebutuhan yang bisa diperoleh manusia, paralel dengan kuantitas yang bisa dan ingin diperoleh oleh setiap manusia.

\section{JENIS BARANG TAMBANG DALAM AL-QUR'AN}

1. Emas:

Emas disebut dengan “adz-dzahab” (الََََّبَ , ج اذْهَاب و ذُهُوبان). Di dalam Al-Qur'an "adz-dzahab", ${ }^{11}$ disebut 7 kali, yaitu sûrat 3: 14, 9: 34, 18: 31, 22: 23, 35: 33, 43: 53 dan 71. Sedangkan kata "dzahaban" disebut satu kali, yaitu dalam sûrat 3: 91.

2. Perak

Perak di dalam Al-Qur'an, dinamai dengan 'AlFidhdhah-الفضضَّة disebut sebanyak 6 kali, dalam sûrah 3: $14,9: 34,43: 33,76: 15,16$, dan ayat $21^{12}$

3. Mutiara

Mutiara dalam Al-Qur'an (اللُوُْْؤَ) disebut sebanyak enam kali. Kata mutiara hampir selalu disebut beriringan dengan kata emas, sehingga bisa disimpulkan bahwa mutiara dianggap setara sebagai sesuatu barang perhiasan baik di

${ }^{10}$ Kevin Healy. "A Theory of Human Motivation by Abraham Maslow (1942-reflection). The British Journal of Psychiatry, vol. 208, Issue. 4, April 2016, hal. 313.

${ }^{11}$ Muhammad Fu'ad 'Abdul al-Baqi. Al-Mu'jam al-Mufahras li Alfazh Al-Qur'an, kairo: Dar el- Hadith, 2005, hal. 340.

${ }_{12}$ Muhammad Fu'ad 'Abdul al- Baqi. Al- Mu'jam al- Mufahras li Alfazh Al-Qur'an, Cairo: Dar el- Hadith, 2005, hal. 632. (entri al-fidhdhah) 
dunia maupun di hari akhir kelak yang bernilai tinggi sebagaimana nilai emas. ${ }^{13}$

Al-Qur'an menyebut kata mutiara yaitu di dalam sûrah 22: 23, 35: 33, 52: 24, 55: 22, 56: 23 dan 76: $19 .^{14}$

4. Batu

Batu di dalam Al-Qur'an, disebut dengan a al-Hajar- آحَجَرُ, dalam Al-Qur'an disebut sebanyak dua kali, dalam sûrat 2: 60 dan 7: 160 dan disebut dengan kata Hijârah sebanyak 10 kali, dalam sûrat 2: 24 dan 74 (dua kali), 8: 32, 11: 82, 15: 74, 17: 50, 51:33, 66: 6, dan 105: $4 .^{15}$

5. Tembaga

Al-Qur'an bicara tentang tembaga, di dalam sûrat Saba'/34 kata آَلَقطْرُ, dimaknai sebagai cairan tembaga, sedangkan pada sûrah al- Kahfi/18 ayat 96- 97, disebutkan kata 'tembaga panas', yakni, dalam kisah pembuatan benteng pertahanan raksasa yang menghubungkan dua gunung dari potongan besi dan meleburnya dengan menggunakan tembaga sebagai pengikatnya, -yang dibangun oleh raja Dzûlqarnaîn-.

6. Besi

Ilmu pengetahuan modern telah menegaskan bahwa besi mengisi sepertiga dari komposisi bumi yaitu kurang lebih 35 persen bersama oksigen 30\%, Magnesium 10\%, Silicon $15 \%$ dan lainnya $10 \%$, sehingga bumi mempunyai kekuatan magnetik menjaga stabilitas gravitasi bumi.

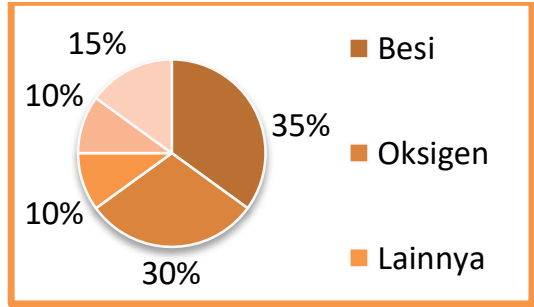

Tabel III. 1 : Komposisi Besi di Bumi

${ }^{13}$ Charlotte Eng and Maria Fusco. "Fish Scales and Faux Pearls: A Brief Exploration into the History of Manufacturing Faux Pearls". Textile History. November 2012, volume 43,.no. 2. hal. 250-259.

${ }^{14}$ Muhammad Fu'ad 'Abdul al-Baqi. Al-Mu'jam al-Mufahras li Alfazh Al-Qur'an, kairo: Dar el- Hadith, 2005, hal. 744.

${ }^{15}$ Muhammad Fu'ad 'Abdul al-Baqi, Al-Mu'jam al-Mufahrâs li Alfazh Al-Qur'an, Kairo: Dar al- Hadith, 2005, hal. 238

${ }^{16}$ Nadhiah Tharayyarah. Sains dalam Al-Qur'an. Diterjemahkan oleh M. Zaenal Arifin, et.al., Dari judul: Mau'sûah Al-'Ijâz Al-Qur'ani, ..., hal. 489. 
Besi di dalam Al-Qur'an, dapat ditemui dengan kata 'alHadîd- الحَدِيد , -sebanyak lima kali, yaitu sûrah 18: 96, 22: 21, 34: 10, 50: 22, 57: 25.

Kata 'Hadîdân- حَدِيدً sendiri disebut sekali dalam sûrat 17: 50. ${ }^{17}$ Di dalam Al-Qur'an tentang kekayaan pertambangan besi menempati-posisi yang tinggi, karena Allah Ta'âlâ menamakan surat Besi pada salah satu bagian di dalam firman-Nya.

7. Tanah Liat

Menurut Kamus Hans Wehr, dry clay disebut dengan al-shalshâl- atau tanah liat, ${ }^{18}$ Munawwir mengartikan الطِيَّنُ الخَزَفَفيُ yang berarti tanah liat yang biasa dibuat tembikar. ${ }^{19}$

Dalam Al-Qur'an 'tanah liat' disebut sebanyak empat kali yaitu sûrat 15 ayat ke-26, 28, 33 dan sûrat 55 , ayat ke-13. ${ }^{20}$ Dari sûrah al- Hijr/15: 26, Wâhbah az-Zuhailî menjelaskan bahwa Allah telah menciptakan Adam atau jenis manusia dari tanah liat kering. Jika tanah liat tersebut dimasak dengan cara dibakar, itu disebut al- fakhkâr (tembikar). Sedangkan dari tanah liat basah (lumpur) yang berwarna hitam karena bercampur dengan air, yang berubah baunya. ${ }^{21}$

8. Ter dan Aspal

Di dalam Al-Qur'an, tir atau aspal disebut satu kali dengan kata 'qathirân', yaitu Ibrâhîm/14: 50.

Keterangan -min qathirân- oleh Wâhbah az- Zuhailî, diartikan sebagai ter/belangkin, yang dijelaskan sebagai zat zat berwarna hitam yang dapat memicu nyala api menjadi semakin besar.

9. Minyak Bumi

17 (1) Muhammad Fu'ad 'Abdul al- Bâqî. Al-Mu'jam al-Mufahras li Alfazh Al-Qur'an, kairo: Dar al- Hadith, 2005, hal. 240. Dan ${ }^{(2)}$ Djamel Ghernout. "The Holy Koran Revelation: Iron is a "Sent Down" Metal". American Journal of Enviromental Protection. vol. 6, nomor 4, 2017, hal. 101-104.

${ }^{18}$ Hans Wehr. A Dictionary of Modern Written Arabic: Arabic-English Diterjemahkan oleh J. Milton Cowan. Beirut: Librairie du Liban. 1974, cet. ke-3, hal. 523.

19 Ahmad Warson Munawwir, Kamus Al-Munawwir Arab-Indonesia, Surabaya: Pustaka Progressif, 1997, cet. XIV, hal. 790.

20 Muhammad Fu'ad 'Abdul Al-Baqî. Al-Mu'jam Al-Mufaras lil Al-Fazh Al-Qur'an Al-Karîm. Kairo: Dar al-Hadith, 2005, hal.507. (entri shalshâlin).

21 Wâhbah az- Zuhailî. Tafsir Al-Munîr: fil 'Aqidah wa al-Syarîah wal Manhaj. ..., jilid 7. hal. 333-338. 
Landasan pemikiran

Abu 'Ubaid al-Qasim (157 H/774 M-224 H-837 M), menjelaskan bahwa Rasullulah Shallâllâhu 'alaihi wasallam pernah memberikan kepada Bilal bin Harits al- Muzani (w. $682 \mathrm{M}$ ) tambang al- Qabaliyah dan al- Aqiq, yang terletak di daerah Muzainah. Dari tambang al-Qabaliyah yang telah dieksplorasi tersebut, Rasulullah mengambil zakat tambang darinya. ${ }^{23}$

Jaribah bin Ahmad al-Haritsi, dalam Al-Fiqh al-Iqthîshôdî li Amiril Mukminin Umar ibn al-Khathab, menjelaskan lebih lanjut bahwa ketika kemudian Umar Radiyâllahu anhu (583 M-644 M) menarik kembali tambang al- Aqiq.

Menurut pendapat yang kuat penarikan kembali itu ditafsirkan, bahwa daerah al- Aqiq, adalah salah satu lembah di Madinah yang disana terdapat harta penduduk Madinah (dalam arti bahwa kepemilikan dan distribusi hasil tambang yang berada di tambang al- Aqiq sangat dibutuhkan guna memenuhi keperluan kaum Muslimin pada masa tersebut). ${ }^{24}$

Hal ini berkesesuaian dengan sabda Rasulullah Shallâllâhu 'alaihi wasallam, tentang pentingnya hal-hal yang disebutkan dalam hadits riwayat Abî Dawud, bagi semua manusia.

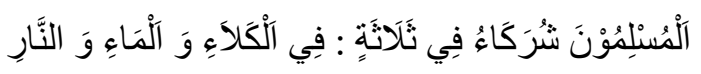

Kaum Muslimin berserikat dalam tiga hal: rumput, air, dan api. (Hadist Riwayat. Abî Dâwud). ${ }^{25}$

Berserikat dimaknai bahwa hal-hal tersebut di atas dilarang dikuasai oleh perseorangan mengingat semua manusia sangat membutuhkannya.

Istilah minyak tanah, petroleum, minyak bumi, bahan bakar minyak (BBM) dan minyak mentah. Canner Taslaman, guru besar sains dan filsafat di Yildiz Technical University,

22 Abu 'Uba'id al-Qasim. Kitâb Al-'Amwâl. Beirut: Dar Kutub Ilmiyah, 1409 H/1989 M, hal. 430-435.

${ }^{23}$ Jarîbah bin Ahmad al- Haritsî. Al-Fiqh al-Iqthîshadî li Amiril Mukminin Umar ibn al-Khaththab. Mekah: Ummu'Al-Qura' University. 1421 H /200 M, cet. III, hal. 231.

${ }^{24}$ Jaribah bin Ahmad al-Haritsi. Al-Fiqh al-Iqthishôdî li-umîril mu'minin Umar bin al-Khathab RadiyâAllahuanhu...., hal. 233.

${ }^{25}$ Abu Dâwud Sulaimân. Abî Dâwud, Damaskus: Dâr al- Fikr, t. t., Jilid III, no. 3477, hal. 278 . 
Turki, dalam The Qur'an: Unchallengable Miracle, ${ }^{26}$ dan Sukandarrumidi, dalam Geologi Minyak dan Gas bumi, ${ }^{27}$ menggunakan kata petroleum, yang berasal dari kata petra yang berarti batuan dan kata oleum yang berarti minyak.

Secara ilmiah terbentuknya minyak bumi, oleh sebagian besar pakar geologi masa kini berdasarkan penelitian ilmiah yang panjang, mendukung teori biotik/organik, yaitu bahwa minyak terbentuk dari sisa-sisa mahluk hidup jutaan tahun yang lampau yaitu Teori Engler-Hofer.

American Petroleum Institute (API) mendukung pendapat di atas, dengan mengadakan penelitian yang mendalam dengan kesimpulan akhir bahwa minyak bumi, batu bara dan gas alam terbentuknya berkaitan dengan keberadaan organisme.

Sejarah penemuan dan pemanfaatan minyak bumi, selama ribuan tahun, khususnya di negara-negara Timur Tengah, adalah berkat doa Nabi Ibrâhîm 'alaihisallam dari surah Ibrâhîm/14: 37. Kemudian di dalam sûrah Fâthir/35: 27, Sayyîd Qûthb menjelaskan hal senada bahwa garis-garis yang dimaksud itu merupakan pembentuk keragaman batubatuan tersebut, baik dalam perbedaan keragaman tingkatan warnanya, bayangannya dan komposisinya, begitu juga dengan warna hitam pekat. ${ }^{28}$

Ibnu Abbas, menekankan al-gharâbib adalah jamak dari ghirbîb yakni, hitam yang sangat pekat, orang mengatakan aswadu ghirbîb) yang di dalam konteks di atas merujuk pada warna minyak bumi, dimana akibat aliran tetesantetesan minyak bumi yang keluar melalui celah-celah bebatuan dan menutupi permukaannya dengan warna hitam pekatnya. ${ }^{29}$

Ringkasnya zat organis penyusun jaringan tumbuhan pembentuk minyak bumi, adalah yang mengandung:

${ }^{26}$ Canner Taslaman. The Qur'an Unchallengable Miracle, Diterjemahkan oleh Ender Gurol, Turkey: Citilembik Publication, 2006, hal. 135.

${ }^{27}$ Sukandarumidi. Geologi Minyak Dan Gas Bumi. Yogyakarta: Gadjah Mada University Press, 2013, cet. I. hal. 1.

${ }^{28}$ Maktabah: Arabic Languange (Complete Edition), Sayyid Qûthb. Tafsir Fi Zilal Al-Quran, hal . hal 35-36. https://tafsirzilal.files.wordpress.com/2012/06/35.pdf.

${ }^{29}$ Ali bin Abi Thalhah. Al-Musamma Shahifah Ali bin Abu Thalhah an Ibni Abbas fi Tafsir Al-Qur'an Al-Karim. Beirut: Mu'asasah al-Kitab Tsaqifiyah. 1411H/ $1991 \mathrm{M}$, hal. 414. 
1) Lignin dan selulosa, terutama dari karbohidrat dan zat kayu.

2) Asam humus, ${ }^{30}$

Lebih jauh Canner Taslaman, dalam The Qur'an: Unchallengable Miracle, menjelaskan secara ringkas terkait pembentukan minyak bumi: ${ }^{31}$

1. Terbuat dari bahan organik (semisal: rumputrumputan).

2. Berwarna kehitaman.

3. Mengalir seperti banjir/air bah, adalah isyarat adanya siklus organisme di bumi dari sudut pandang biologi, selaras dengan sûrat al- A'lâ/87 ayat 4-5, sebagai berikut, : Dan yang menumbuhkan rumput-rumputan. Lalu dijadikan-Nya rumput-rumput itu kering kehitam-hitaman. (al- A'lâ/87: 4-5).

Quraish Shihab dalam Tafsîr Al- Mishbâh, menerangkan bahwa kata (المَرعى) al- mar'â terambil dari kata (رعى) ra'â, yang kemudian arti menyempit menjadi 'rerumputan. ${ }^{32}$

Ayat kelima, Diriwayatkan oleh Ibnu Abbas dari AlThâbarî dalam Jami' al Bayan an Ta'wil Ayi Al-Qur'an,

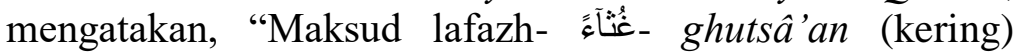
adalah hasyîman mutaghayyiran yaitu tumbuh-tumbuhan kering yang berubah".

Kemudian dari al-Suyûthi dalam Al-Itqan fí 'Ulum AlQur'an, yang dinukil oleh Ibnu Abbas menafsirkan kata آحوى - ahwâ adalah "kehitam-hitaman". Ia berkata, "Maksudnya adalah berwarna hitam". 33

Penegasan kriteria terbentuknya minyak juga terdapat pada sûrah al- Mu'minûn/23: 41, Al-Marâghî mengartikan

${ }^{30}$ Sukandarumidi. Geologi Minyak dan Gas Bumi. ..., 2013, hal. 86.

31 Canner Taslaman. The Qur'an: Unchallengable Miracle. Diterjemahkan oleh Ender Gurol, Turkey: Citlembik Publication, 2006, hal. 135.

${ }^{32}$ M. Quraish Shihab. Tafsîr Al-Misbâh: Pesan, Kesan dan Keserasian AlQur'an. Jakarta: Lentera Hati, 2012, cet. V, hal. 238. (Digunakan majas mursal).

${ }^{33}$ Ali bin Abû Thalhâh. Al-Musammâ Shahîfah Ali bin Abû Thalhâh an Ibnî Abbâs fî Tafsîr Al-Qur'an al-Karîm (Tafsir Ibnu Abbas). Beirut: Mu'asasah al-Kitab al-Tsaqifiyah. 1411 H/ 1991 M. hal. 528. 
"ghutsâ'an" sebagai sampah banjir. ${ }^{34}$ Minyak bumi menunjukkan sifat 'air bah' dan berperilaku seperti banjir.

Secara ilmiah minyak bumi sering bergerak menjauh dari tempat semula ia terbentuk dan tidak memiliki sifat menetap. Menempuh jarak yang jauh dan berkumpul pada titik-titik tempat ia melintasi bebatuan yang keras tanpa pori-pori dimana cadangan minyak bumi ditemukan di tempat-tempat ia ditemukan sebagai deposit, terhalang dalam melanjutkan perjalanannya. Allah merancang komposisi senyawa ini sedemikian rupa sehingga bisa dimanfaatkan untuk berbagai kebutuhan hidup manusia. ${ }^{35}$

Tafsir Salman juga menegaskan, bahwa tumbuhan mempunyai kemampuan mengikat karbondioksida dari atmosfir menjadi karbohidrat lewat proses fotosintesis. Ketika menjadi fosil, ${ }^{36}$ karbohidrat pada tumbuhan tersebut terurai kembali dan menyisakan karbon. Selain itu, kedua ayat sûrat al-A'lâ/87 juga dapat ditafsirkan menggambarkan bioma gurun. Sebab di lingkungan gurun, seringkali rerumputan terbakar karena panas hingga menjadi sekam yang kehitam-hitaman sehingga minyak mudah ditemui di daerah tersebut. ${ }^{37}$

10. Sumber Daya Energi Tenaga Air (Hidroelektrik)

Di dalam Al-Qur'an ada dua kata yang dapat dipahami sebagai laut yaitu al-bahr-البحر, sungai yang sangat lebar disebut juga al-bahr. Jamaknya adalah al-bihâr, yang dapat diartikan sebagai samudera, laut yang sangat luas.

Di dalam Al-Qur'an kata laut- البحر, disebut 43 kali, yaitu pada sûrat $/ 2: 50,164,5: 96,6: 59,63,97,7: 138,163,10$ : 22, 90, 14: 32, 16: 14, 17: 66, 67, 70, 18: 61, 63,79, 109, 20: 77, 22: 65, 24: 40, 25: 53, 26: 23, 27: 61, 63, 30:41,

${ }^{34}$ Ahmad Mustafa al- Mârâghî, Tafsîr Al-Maraghî, Mesir: Mustafa alBâbî al- Halabi, 1394 H/ 1974 M, juz XVI, hal. 39.

${ }^{35}$ Inda Hamidah (ed), Kerajaan Al-Qur'an, Jakarta: Penerbit Almahira, 2012, cet. I, hal. 152 .

${ }^{36}$ Kata fosil berasal dari bahasa Latin, fossilis, yang artinya sesuatu yang digali atau fodere yang berarti menggali. Pengertian fosil adalah segala sisa peninggalan binatang dan tumbuhan yang telah membatu dan terawetkan. Ilmu yang mempelajari tentang fosil adalah paleontologi, yang berasal dari bahasa Yunani Palaios yang berarti tua atau kuno dan onta yang berarti yang ada, atau hidup, serta logos yang artinya ilmu. (lihat: Agung Mulyono, Pengantar Ilmu Kebumian, Bandung: Pustaka Setia, 2008, ed. rev. cet. II, hal. 119).

37 Ahmad Baiquni (ed). Tafsir Salman: Tafsir Ilmiah Juz 'Amma. Bandung: Mizan Media Utama, 2014, cet. I, hal. 271. 
$31: 27,31,35: 12,42: 32,44: 24,45: 12,52,6,55: 19,24$, 81: 6 , dan sûrat 82: $2 .^{38}$

11. Sumber Daya Tenaga Surya

Muhammad al-Baqi mengklasifikasikan di dalam AlQur'an kata الثمس sebanyak 31 kali yakni sûrat 2: 258, 6: 78, 96, 7: 54, 10: 5, 12: 4, 13: 2, 14: 33, 16: 12, 17: 78. 18: 17, 86, 90, 20:130, 21:33, 22: 18, 25: 45, 27: 24, 29: 61, 31: 29, 35: 13, 36: 38, 40, 39: 5, 41: 37, 50:39, 55: 5, 71: 16, 75: 9, 81: 1, $91: 1$ dan 1 شَمَسًا , disebut sekali dalam sûrat al-Insân/76: $13 .^{39}$

12. Sumber Daya Energi Tenaga Angin

Di dalam Al-Qur'an kata 'angin' (al-rih/ bentuk tunggal atau riyâh/bentuk jamak) disebut sebanyak 13 kali di 13 sûrat yang berbeda yaitu: $3: 117,10: 22,12: 94,14: 18,17$ : 69, 21: 81, 22: 31, 34: 12, 38: 36, 42: 33, 46: 24, al- 51: 41, dan 69: 6.

Selanjutnya kata Rîhân disebut dalam lima sûrat yaitu: 30: 51, 33: 9, 41: 16, 54: 19, /8: 46. Serta kata Rîyah disebut sebanyak 10 kali yaitu pada 2: 164, 7: 56, 15: 22, 18: 45, 25: 48, 27: 63, 30: 46, 48, 35: 9, dan 45: 5. ${ }^{40}$

13. Sumber Daya Energi Panas Bumi (Geothermal)

Sumber daya energi panas bumi (Geothermal) dari perspektif sains di dalam Al-Qur'an, pada sûrah alThûr/52: 6 .

\section{KONSEP AL-QUR'AN TERKAIT ETIKA EKSPLORASI PERTAMBANGAN}

\section{A. Hakikat Etika Religius/Ilahiyyah}

Peran etika religius Islam dalam dunia modern terpenting yaitu tipe nilai dan moral etis etika dimana keputusan etikanya berdasar pada al-Quran, dan al-Sunnah. ${ }^{41}$ Sebagai bagian dari ilmu filsafat etikapun tidak berhenti hanya pada yang konkret, pada yang secara faktual dilakukan, tetapi ia bertanya pada apa

\footnotetext{
${ }^{38}$ Muhammad Fu'ad 'Abd al-Baqi. Al-Mu'jam al-Mufahras li al-Fazh AlQur'an. Kairo: Dâr al Hadith. 2005, hal. 140

${ }^{39}$ Muhammad Fu'ad 'Abd al-Baqi. Al-Mu'jam al-Mufahraz li Alfazh AlQur'an. ..., hal. 476.

${ }^{40}$ Muhammad Fuad 'abd. Al-Baqi. Al-Mu'jam al-Mufahras li Al-Fazh AlQur'an. Kairo: Dar al-Hadith, 2005, hal. 400.

${ }^{41}$ Sudarsono. Ilmu Filsafat. Jakarta: Peenerbit Rineka Cipta, 2008, hal. 218.
} 
yang harus dilakukan atau tidak boleh dilakukan, tentang yang baik atau buruk untuk dilakukan. ${ }^{42}$

Bila etika Barat sifatnya "antroposentrik" (berkisar sekitar manusia) atau paradigma selainnya yang diyakininya. maka etika Ilahiyyah bersifat "teologis" (pemikiran yang berpusat pada Tuhan), juga memiliki sifat teleologis (mementingkan tujuan akhir). Dalam etika Ilahiyyah, suatu perbuatan selalu dihubungkan dengan amal saleh atau dosa dengan pahala atau siksa, dengan surga atau neraka.

\section{B. Hakikat Baik dan Buruk dalam Al-Qur'an}

Persoalan etika pada dasarnya lebih berada pada dataran aplikatif, dilihat dari segi aplikasi nilai-nilai etika tersebut di dalam realitas kehidupan, bisa saja terjadi perbedaan-perbedaan. karena dalam realitas kehidupan konkret, berbagai dilematik muncul dan nilai-nilai etika yang universal dan absolut itu menghadapi tantangan yang kompleks, yang tidak sepenuhnya dapat dijalankan dengan mulus. ${ }^{43}$

Dalam konsep filsafat Islam, yang baik itu disebut alma'ruf artinya semua orang secara kodrati tahu dan menerimanya sebagai kebaikan, terdapat manfaat dan kebaikan manusia baik di dunia maupun di akhirat oleh syara' dan akal. Sedangkan yang buruk itu disebut al-munkar yaitu semua orang secara kodrati menolak dan mengingkarinya yang dipandang dari sudut syara' dan akal. ${ }^{44}$ Di dalam surat Ali Imran/3 ayat 104 dikatakan bahwa: Dan hendaklah ada di antara kamu segolongan umat yang menyeru kepada kebajikan, menyuruh kepada yang ma'ruf dan mencegah dari yang munkar; merekalah orang-orang yang beruntung. (Âli Imrân/3: 104). Etika Ilahiyyah: Hubungan Manusia dan Tuhan

\section{Hakikat Etika Eksplorasi Pertambangan menurut Al- Qur'an}

Aktivitas manusia dalam eksplorasi pertambangan dapat dikatagorikan sebagai kegiatan ekonomi/Iqthisôdiyyah. Yusuf Qaradhawi menjelaskan bahwa Iqthisôdiyyah, bisa disebut

${ }^{42}$ Kees Berthens. Etika. Jakarta: Kanisius, 2013, hal. 21.

43 Musa Asy'arie. Filsafat Islam: Sunnah Nabi dalam Berfikir. Yogyakarta: LESFI, 2010, cet.ke-5, hal. 96.

44 John Penrice. A Dictionary and Glossary of the Koran. Delhi: S. Sajid Ali for Adam Publisher, 1991, hal. 51-96. 
dengan ekonomi Ilahiyyah, karena titik tolak dari Allah, tujuannya mencari ridha Allah dan cara-caranya tidak bertentangan dengan syari'at-Nya, baik itu kegiatan ekonomi, eksplorasi, produksi, konsumsi maupun distribusi yang diikatkan pada nilai-nilai dan norma-norma 'akhlaq dari ajaran Islam. ${ }^{45}$

\section{IMPLEMENTASI ETIKA EKSPLORASI PERTAMBANGAN PERSPEKTIF AL-QUR'AN}

Nilai moral dan etika banyak dipengaruhi oleh dorongan hawa nafsu. Pengertian hawa nafsu dapat dikarakterisasikan dengan berbagai sifat sesuai dengan kondisi yang berbeda-beda yaitu: ${ }^{46}$

a. Nafs al-muthmainah/jiwa yang tenteram atas perintah dan larangan dan bergetar manakala berhadapan dengan syahwat. (al-Fajr/98: 28).

b. Nafs al-lawwâmah/jiwa pencela, yakni jiwa yang tidak merasakan ketenangan, tetapi melawan dan menentang dorongan syahwat dan amarah. (al-Qiyâmah/75: 2).

c. Nafs al-ammarah/jiwa yang tunduk pada tuntunan syahwat dan ajakan setan.(kisah Nabi Yusuf 'Alaihisallam, pada sûrah Yûsuf/12: 53).

Hikmah di atas adalah pentingnya mengutamakan etika dalam suatu keputusan dalam bidang apa saja, khususnya dalam industri eksplorasi pertambangan, hendaknya semua aktivitas bernilai amal saleh, dengan tujuan akhir yakni untuk memperoleh surga yang penuh dengan berbagai kenikmatan.

\section{PENUTUP}

Tujuan dari perwujudan etika eksplorasi pertambangan Qur'anik adalah kesadaran potensi diri manusia beretika di dalam ranah pertambangan guna memperoleh kebaikan yang utama (summum bonum).Bukan sebaliknya bahwa sumber tambang hadir bebas untuk dieksploitasi oleh manusia, namun dipahami sebagai sarana manusia guna menunaikan tugasnya sebagai khalîfah fî-al-'Ardh dengan tujuan teleologis yaitu kehidupan di akhirat kelak, yakni memperoleh istana di surga

\footnotetext{
${ }^{45}$ Yusuf al-Qaradhawi. Dâr al-Qiyam wa Akhlaq fil Iqthishod al-Islami. ..., hal. 23.

${ }^{46}$ Faidh Kasyani. Etika Islam Menuju Evolusi Diri. Diterjemahkan oleh Husain al-Kaff, Dari Judul: Al-Haqâ' 'iq fì Mahâsin al-Akhlâq. Jakarta: Sadra Press, 2014, hal. 54.
} 
'Adn. Kelalaian manusia dan ketidak'sujud'an manusia di muka bumi membuktikan bahwa manusia mengabaikan tujuan keutamaan kebaikan tertinggi (summum bonum) dari etika, bahwa sanksi di dunia jelas tampak menuruti hukum/sunnatullah alam yaitu dengan diturunkannya azab banjir, banyaknya bencana alam hingga malapetaka adanya perubahan iklim.

Manusia dengan independensinya dalam memilih posisi kebaikan atau posisi keburukan pada akhirnya harus memahami bahwa semua perbuatannya akan dimintai pertanggungjawabannya kelak. Untuk mencapai tujuan tertinggi di dunia berupa kebaikan, manusia tidak sekedar memandang seharusnya mereka berbuat (what should I do), namun lebih dari itu manusia harus memahami bagaimana mereka mewujud manusia (what should I be). Etika eksplorasi pertambangan perspektif Al-Qur'an mengarahkan perilaku setiap individu tanpa kecuali pada sebentuk perilaku yang bukan hanya lip service belaka ataupun hanya di tataran teori apalagi mistis, namun sampai kepada nilai-nilai dan norma-norma etis yang sepatutnya.

Konformitas nilai-nilai keutamaan etika eksplorasi pertambangan perspektif Al-Qur'an dapat dirangkum sebagai berikut yaitu:

1. Ista'mar, Ke'sujud'an/ketundukan, posisi manusia sebagai 'abdullah (al-An'am/6: 165, Fathîr/35: 39 dan Shâd/38: 28), dan adanya harapan balasan perbuatan (al-Hajj/22: 18: al-An'am/6: 162:163).

2. Iradah/Independensi, sebagai fitrah manusia (al-Rûm/30: 30) yaitu fitrah keleluasaan/kebebasan/berkehendak (alQashâsh/28: 77 dan al-Hajj/22:18).

3. Ihsan, menunaikan semua kewajiban dan menjauhi semua keburukan di dalam menjaga hubungan-intensionalitasnya dengan Allah Ta'âlâ maupun relasi kuatnya terhadap manusia (Âli Imrân/3: 148 dan al-Maidah/5:85).

4. Itqan, rapi dan paripurna dalam sesuatu yang memerlukan keahlian/bekerja secara professional (al-Naml/27: 88).

5. Inter-dependensi/ketersalingan: a). Pemahaman urgensi alam bagi manusia yang dirancang dan diciptakan Allah bukan kebetulan dan memiliki tujuan (Âli Imrân/3: 191 dan Shâd/38: 27). Implikasi hubungan intensionalitas alam dan manusia (Âli Imrân/3: 14-15: al-Nûr/24: 55-56) 
dengan tujuan asas ke'Adil'an (al-Hadîd/57: 25, alNisâ'/4: 58)

6. Iltizam, Bermakna kuat 'mujahadah dan berpegang teguh menjaga/ istiqomah (Ẩli Imrân/3: 103, alAhqaf/46:13, al-Baqarah/2: 256)

7. Harmoni bersinergis:

a) Persaudaraan dan partisipatoris (al-Maidah/5: 2) dan

b) Konformitas/keselarasan (al-Qashash/28: 77).

\section{DAFTAR PUSTAKA}

Al-Qur'an Al-Karim.

Abbadiko, Getahun Hassen. "The Role of Climate-ForestAgriculture Interface in Climate Resilient Green Economy of Ethiopia". Internal Journal of Suistanable and Green Energy, vol. 5, no.6, 2016, hal. 111-126.

Abdillah, Mujiono. Agama Ramah Lingkungan. Jakarta: Paramadina, 2001.

Abduh, Muhammad dan Ridhā, Rasyîd. Tafsîr Al-Manār, Kairo: Dār al-Manār, 1948, cet. II.

Abdullah, Mudhofir. Al-Qur'an dan Konservasi Lingkungan. Jakarta: Dian Rakyat. 2010. cet. I.

Abdullah, Muhammad Hamid. Iqthishodiyyat al-Mawarid. Riyadh: Jami'ah al-malik Sam'ud, 1441 H/1991 M, cet. I.

Abdullah, Oekan S. Ekologi Manusia dan Pembangunan Berkelanjutan. Jakarta: Gramedia. 2017.

Abdullah, Rahmat. Teori Absolutivitas Matahari Mengelilingi Bumi. Solo: Pustaka Arafah.2011.

Abdurrahman, "Abdullah bin Muhammad bin bin Ishaq Alu Syaikh. Lubâbut Tafsîr min Ibnî Katsîr. Kairo: Mu'assasah Dâr al-Hilâl. 1414 H/1994 M, cet. 1, jilid 5.

Abdurrahman, dan Elam Sumarna. Metode kritik Hadits. Bandung: Penerbit Rosda. 2011. 
Abu, 'Ubaid. Al-Amwāl. Beirut: Dar Kutub Ilmiyah, t.th.

Abu, Zahrah Muhammad. Ushul Fiqh. Diterjemahkan oleh Saefullah Ma'shum. Dari judul Al- Fiqh 'ala al-Madzahib al-Khamsah, Jakarta: Penerbit PT. Pustaka Firdaus, 2010, cet XIII.

Adam, J. S. "Toward an Understanding of Inequity". Journal of Abnormanl Psychology, vol. 67, hal 422-436.

Adams, Carol. J. Ecofenimism and The Sacred. New York: The Continuum Publishing Company. 1993.

Adhikari, Bhim. Literature Review on The Economics of Common Property Resources. York: University of York, 2001.

Adian, Donny Gahral. Pengantar Fenomenologi. Depok: Penerbit Koekoesan. 2016. cet. II.

Aducci, Mathilde. "Neo-Iiberalism, Mining and Labour in The Indian State of Odisha: Outlining a Political Economy Analysis." Journal of Contemporary Asia; Abingdon, Oxfordshire,vol. 47, no. 4, September 2017, hal. 569-614.

Ahmad, Shafaat. "Ecology and The Teachings of the Prophets Muhammad and Jesus". Journal Islamic Perspectives. Retrieved 1 December 2012.

Aissatou, Ndiaye, et.al.."Global warming and Heat Waves in West-Afica: Impact on Electricity Consumption in Dakar (Senegal) and Niamey (niger)". International Journal of Energy and Enviromental Science. Vol. 2, no. 1, 2017, hal 16-26.

Ajaj, Muhammad al- Khatib. 'Ushul al- Hadits- Pokok-Pokok Ilmu Hadits. Diterjemahkan oleh HM Qodirun Nur dan Ahmad Musyafiq. Dari judul 'Ushul al-Hadits. Jakarta: Penerbit Gaya Media Pratama, 2013, cet. V. 
al-Asfaghani, Husein Muhammad ar-Raghib. Mufradat $F \hat{\imath}$ Gharîbil Qur'an. Mesir: Dar Ibnul Jauzi, t.th.

al-Asqallani, Ibn Hajar. Fathul Bari, Bab La Hima Illa Lillahi wa Li Rasulihi. Qahirah: Dar Misr, 1421 H/2001 M, Juz 6.

al-Bantani, Nawawi. Mārāh al-Labîd. Beirut: Dār al-Kutub al'Ilmiyyah, 1997.

al-Baqi, Muhammad Fu'ad 'Abdul. Al-Mu'jam al-Muhfahras Li Al-Fazh Al-Qur'an. Kairo; Dar-El-Hadith, 2005.

al-Basyuni, Hamid Ahmad At-Thahir. Shahih Qashashil AlQur'an. Kairo: Darul Hadits. 2005.

al-Biruni, Abu Raihan. Al-Jamhir fi Mari'fatul al-Jawahir. Diterjemahkan oleh H. M. Said, Dari Judul The Book Most Comprehensives in Knowledge on Precious Stone. Islamabad: Hijrah Council, 1989.

al-Bugha, Mustafa. Syarh Al-Arba'in An-Nawawiyah. Mesir: Dar Ibn Katsir, 1993 M/1413 H.

al-Bukhari, Muhammad Ibn Isma'il. Shahîh al-Bukhâri. Kairo: al-Mathba'ah as Salafiyyah, $1400 \mathrm{H}$.

al-Hamouda, dan Bingsen Wangb."A review of the state-of-theart in wind-energy reliability analysis". Renewable and Susitanable Energy Reviews, vol. 81, no.2, Januari 2018, hal. 1643-1651.

al-Hujwairi, Alî Ibn 'Ustman. The Kasfy al-Mahjub. New Delhi: Taj Company, 1982.

Ali, Parveen S. Humans Rights in Islam. New Delhi: Adam Publishers. 2007.

Ali, Saleem H. "Mining Dilemma". Alternatives Journal (AJ)Canada's Environmental Voice, volume 35, no. 1, Febuary 2009, hal. 8-11. 
Alikodra, Hadi S. Konservasi Sumber Daya Alam dan Lingkungan. Jogjakarta: Gadjah Mada University Press, 2012.

Aneesuddin, Mir. The Universe Seen through Al-Qur'an. Canada: Al-Attique Publishers Inc, 1999. 